\title{
ОСОБЛИВОСТІ РЕКЛАМНОГО МЕНЕДЖМЕНТУ В КОКСОХІМІЧНІЙ ГАЛУЗІ: АСПЕКТИ ВІРТУАЛІЗАЦІї
}

\section{FEATURES OF ADVERTISING MANAGEMENT IN THE COKE INDUSTRY: ASPECTS OF VIRTUALIZATION}

\author{
Рудика Віктор Іванович \\ доктор економічних наук, директор, \\ Державний інститут по проектуванню підприємств \\ коксохімічної промисловості «Гипрококс» \\ ORCID: https://orcid.org/ 0000-0002-2447-8442 \\ Rudyka Victor \\ State institute for designing enterprises \\ of coke oven and by-product plants «GIPROKOKS»
}

\begin{abstract}
Одним із інструментів для здійснення успішної діяльності на промислових підприємствах, в тому числі й на підприємствах коксохімічної галузі, є рекламний менеджмент. Сьогодні серед інструментів рекламного менеджменту важливу роль стали відігравати цифрові технології. В статті досліджено сутність рекламного менеджменту, визначено його інструменти. Проведено порівняльний аналіз моделей рекламного менеджменту. Обґрунтовано, що для ефективної діяльності коксохімічних підприємств необхідно запроваджувати новітні технології та застосовувати концепцію В2В маркетингу, які включають пошукове просування; контекстну рекламу; e-mail-маркетинг; інструменти всередині В2В-сайту; прихований маркетинг; роботу з блогами, соціальними мережами тощо. Сформовано основні особливості сучасного рекламного менеджменту на В2В ринках в цілому та ринку коксохімічної продукції зокрема. Виявлено тренди сучасного рекламного менеджменту, які необхідно впроваджувати на підприємствах коксохімічної промисловості.
\end{abstract}

Ключові слова: рекламний менеджмент, підприємства коксохімічної промисловості, маркетинг, В2В маркетинг, віртуалізація, рекламні тренди.

Одним из инструментов для осуществления успешной деятельности на промышленных предприятиях, в том числе и на предприятиях коксохимической отрасли, является рекламный менеджмент. Сегодня среди инструментов рекламного менеджмента важную роль стали играть цифровые технологии. В статье исследована сущность рекламного менеджмента, определены его инструменты. Проведен сравнительный анализ моделей рекламного менеджмента. Обосновано, что для эффективной деятельности коксохимических предприятий необходимо внедрять новейшие технологии и применять концепцию В2В маркетинга, которые включают поисковое продвижение; контекстную рекламу; е-таil-маркетинг; инструменты внутри В2В-сайта; скрытый маркетинг, работу с блогами, социальными сетями и др. Сформированы основные особенности современного рекламного менеджмента на В2В рынках в целом и рынка коксохимической продукции в частности. Выявлено тренды современного рекламного менеджмента, которые необходимо внедрять на предприятиях коксохимической промышленности.

Ключевые слова: рекламный менеджмент, предприятия коксохимической промышленности, маркетинг, В2В маркетинг, виртуализация, рекламные тренды.

One of the tools for successful activities for industrial enterprises, including coke industry enterprises, is advertising management. It allows the use of advertising technology to promote industrial products. Today, among the tools of advertising management digital technologies began to play an important role. That reflect current trends in advertising space and doing business in the context of virtualization and digitalization. These trends have also become especially relevant in the context of the COVID-19 pandemic, when the use of Internet technologies has become a condition for survival in all spheres of society. Therefore, the purpose of the article was to substantiate the list of basic tools of advertising management and determine the main directions of their virtualization in the coke industry. The article explores the essence of advertising management, identifies its main tools. A comparative analysis of advertising management models - marketing paradigms is conducted. It is substantiated that for effective 
activity of coke chemical enterprises it is necessary to introduce the latest technologies and apply the concept of B2B marketing, which includes search promotion; contextual advertising; e-mail marketing; tools inside the B2B site; covert marketing; work with blogs, social networks, etc. The main features of modern advertising management in $\mathrm{B} 2 \mathrm{~B}$ markets in general and the market of coke products in particular are formed. Among the trends of modern advertising management are identified: content marketing and content marketing strategy; customer-oriented approach in marketing; integration of marketing data; holistic approach to marketing; adaptation to a common screen; creating your own Internet applications; media sponsorship and creation of media platforms; use of online stores and online services. Based on the current trends in the field of virtualization in the development of advertising management measures will allow the coke industry to increase sales.

Keywords: advertising management, coke industry enterprises, marketing, B2B marketing, virtualization, advertising trends.

Постановка проблеми. Розвиток сучасних тенденцій в інфрормаційній сорері, який ускладнює конкурентне середовище призводить до появи нових вимог до рекламного менеджменту.

Слід відзначити наявність наступних основних топ-трендів, які найбільше впливають на рекламний простір та пов'язані 3 розвитком цисррових технологій: зміна ступеню доступності, відкритості, рухливості каналів комунікації та типів мережевої взаємодії, який створює нові моделі споживчої поведінки; поява нових форм реклами на основі мультимедійних технологій; зростання впливу соціальних мереж на всі ссрери людського життя; поява нових моделей бізнесу в інтернеті та таких категорій як онлайн-репутація; економіка уваги та економіка вражень; персоналізації як основи просування будь-якого товару та бізнесу; глобалізації бізнес-комунікацій; тощо.

Аналіз ринку інтернет-реклами, оприлюднений в [1] показав, що в Україні за останні 3 роки цей ринок збільшився на $44 \%$, а основними видами реклами в 2020 році стали: пошукова та банерна реклами, нестандартні рішення, спонсорство.

Усвідомлення важливості цих тенденцій та їх впливу на всі сорери життя підприємств вимагає переосмислення інструментарію та технологій рекламного менеджменту.

Аналіз останніх досліджень і публікацій. Значний внесок у розроблення сучасних концепцій та прикладного інструментарію рекламного менеджменту міститься в роботах таких зарубіжних класиків маркетингу як: Ф. Котлер, Ж.-Ж. Ламбен, Ел. Райс, Дж. Траут, Дж.Р. Еванс, а також вітчизняних учених: Л. Балабанової, С. Ілляшенка, М.А. Окландера, І. Решетнікової, А. Войчака. Дослідженню різних аспектів сучасного сектора B2B, до якого належать промислові підприємства приділена увага такими авторами: М. Бек, Р. Райт, Ф. Котлер, Р.Ф. Лаутерборн, С. Минетт, Гр. Дункан, М. Харісон, Д. Шульц,
Ф. Уэбстер, Д. Козьє, Е. Нельсон, М. Хут, Т. Спех, А. Саммер, О. Кендюхов, О. Кузьмін, Й. Петрович, Л. Пономаренко, Н. Васильєва, О. Юдін та інші. Специфріці промислового маркетингу присвячено наукові праці таких відомих учених, як А. Ковальов, А. Длігач, Є. Крикавський, О. Новиков, П. Перерва, Н. Чухрай, А. Старостіна, О. Тєлєтов, в роботах яких розкриваються особливості рекламної діяльності на промислових підприємствах.

Однак, приділення недостатньої уваги проблемам теорії та практики рекламного менеджменту, неоднозначність оцінювання ролі нових засобів комунікації у розвитку процесів на мікро- та макрорівнях в сучасних умовах, неопрацьованість сучасних рекламних технологій в Україні обумовили вибір теми, визначили мету, завдання дослідження

Формулювання цілей статті. Мета статті полягає в обґрунтуванні переліку основних інструментів рекламного менеджменту та визначенні основних напрямків їх віртуалізації на підприємствах коксохімічної галузі.

Основні результати дослідження. Високоякісна інорормативна реклама - це найдорожчий інструмент рекламного менеджменту, який в інтересах підвищення продажу промислових підприємств повинен виконувати такі завдання: пропагувати як товар(послугу), так і фрірму, стимулювати попит і зацікавлення споживачів; інфрормувати і нагадувати про сприятливі можливості вибору і придбання; впливати на попит і пропозицію шляхом дослідження і прогнозування вимог і бажань споживачів.

Можна погодитись з Л. Мороз та Н. Чухрай, які розглядають рекламний менеджмент як процес взаємодії основних учасників рекламної діяльності, об'єктами управління в якому $€$ потенційні споживачі, торгівельні посередники, громадськість та інші, а дія на об'єкти рекламного впливу здійснюється за допомогою інструментів: рекламних звернень, заходів просування, комплексних рекламних кампаній комунікатора [2, с. 215]. 
В2В, як бізнес-модель полягає в створенні постачальником (продавцем) економічної, соціальної та інших фрорм вартості, за рахунок постачання іншим компаніям товарів і послуг, для яких ці товари $є$ не об'єктами споживання в середині підприємства, а бізнесу на промисловому ринку. Моделлю бізнесу В2В можна назвати будь-який бізнес, коли компанія-покупець використовує продане (поставлене) їй 3 метою перепродажу, корінної модернізації або модинга, кастомізації товару і створення тим самим нового товару або послуги [3, с. 52]. Як зазначено в [4, с. 76], під поняттям В2В також маються на увазі також системи електронної комерції, або системи електронної торгівлі. Слушним $€$ зауваження О. Пісної, наведене в [5, с. 92], що В2В-маркетинг - діловий, промисловий, індустріальний маркетинг, орієнтований (спрямований) не так на кінцевого, рядового споживача, а на компанії, тобто на інший бізнес. В2В-маркетинг - поняття, визначене ще Ф. Котлером в [6, с. 54]. як маркетингові відносини між двома сторонами - промисловими підприємствами. Аналогічне трактування наведено в [7, с. 32]. «В2В-маркетинг - це мистецтво створення конкурентної переваги для промислових компаній». Більш сучасне визначення цієї категорії наведено в роботі [8, с. 63], де його визначено як «число бізнес-моделей, які постійно збільшуються і спрямовані на продаж послуг або товарів юридичним особам або на побудову дилерської мережі (згодом дилери перепродують продукцію юридичним чи фрізичним (B2C) особам)». Серед особливостей В2В-маркетингу, насамперед, зазначимо, що йому властива висока ступінь фрункціональної взаємопов'язаності, більш тісний зв'язок із загальною корпоративною стратегією, також слід зазначити технічну складність продуктів та більш тісні зв'язки 3 клієнтами, глибше знання їх потреб, а отже - складність самого процесу закупівлі.

Новітні дослідження рекламного менеджменту в частині його моделей, які оприлюднені в роботах $[5 ; 7 ; 10 ; 11]$ дозволяють порівняти його основні рушійні сили, які існують у всіх парадигмах маркетингу, які працюють на сучасних підприємствах (табл. 1).

Для успішної роботи коксохімічним підприємствам на промисловому ринку необхідно використовувати новітні технології та цілий спектр можливостей для просування В2В-

Порівняння парадигм маркетингу 1.0, 2.0, 3.0 та 4.0*

\begin{tabular}{|c|c|c|c|c|}
\hline & $\begin{array}{c}\text { Маркетинг } 1.0 \\
\text { товаро-центризм }\end{array}$ & $\begin{array}{c}\text { Маркетинг } 2.0 \\
\text { клієнто-центризм }\end{array}$ & $\begin{array}{c}\text { Маркетинг } 3.0 \\
\text { людяний } \\
\text { маркетинг }\end{array}$ & $\begin{array}{c}\text { Маркетинг } 4.0 \\
\text { психологія } \\
\text { поведінки } \\
\text { споживача } \\
\end{array}$ \\
\hline Завдання & Продати продукт & $\begin{array}{l}\text { Задовольнити } \\
\text { потреби } \\
\text { споживача }\end{array}$ & $\begin{array}{l}\text { Зробити } \\
\text { Світ краще }\end{array}$ & $\begin{array}{l}\text { Максимальне } \\
\text { задоволення } \\
\text { інтересів продав- } \\
\text { ців та споживачів }\end{array}$ \\
\hline $\begin{array}{l}\text { Сподвижна } \\
\text { сила }\end{array}$ & $\begin{array}{l}\text { Промислова } \\
\text { революція }\end{array}$ & $\begin{array}{l}\text { Інфоромаційні } \\
\text { технології }\end{array}$ & $\begin{array}{l}\text { Нова хвиля } \\
\text { технологій }\end{array}$ & $\begin{array}{l}\text { Промисловість } \\
4.0\end{array}$ \\
\hline $\begin{array}{l}\text { Як компанії } \\
\text { бачать ринок }\end{array}$ & $\begin{array}{l}\text { Маса покупців } \\
\text { з потребами }\end{array}$ & $\begin{array}{l}\text { Розумний споживач } \\
\text { 3 інтелектом та } \\
\text { серцем }\end{array}$ & $\begin{array}{l}\text { Людина } \\
3 \text { інтелектом, } \\
\text { серцем і духом }\end{array}$ & $\begin{array}{l}\text { Поведінка } \\
\text { споживачів }\end{array}$ \\
\hline \begin{tabular}{|l|} 
Ключова \\
концепція \\
маркетингу \\
\end{tabular} & $\begin{array}{l}\text { Розвиток } \\
\text { продукту }\end{array}$ & Дісрореренціація & Соціальні цінності & $\begin{array}{l}\text { Вплив } \\
\text { на поведінку } \\
\text { споживача } \\
\end{array}$ \\
\hline \begin{tabular}{|l|} 
Напрями \\
маркетингової \\
діяльності \\
компанії \\
\end{tabular} & $\begin{array}{l}\text { Специфрікація } \\
\text { продукту }\end{array}$ & $\begin{array}{l}\text { Позиціонування } \\
\text { компанії } \\
\text { та продукту }\end{array}$ & $\begin{array}{l}\text { Корпоративні } \\
\text { місія, бачення, } \\
\text { цінності }\end{array}$ & $\begin{array}{l}\text { Стратегія, } \\
\text { просування } \\
\text { кастомізованного } \\
\text { продукту } \\
\end{array}$ \\
\hline Пріоритет & Функціональ-ність & $\begin{array}{l}\text { Функціональність } \\
\text { та емоціональність }\end{array}$ & $\begin{array}{l}\text { Функціональність, } \\
\text { емоціональність, } \\
\text { духовність }\end{array}$ & $\begin{array}{l}\text { Задоволення } \\
\text { індивідуальних } \\
\text { потреб }\end{array}$ \\
\hline $\begin{array}{l}\text { Взаємодія } \\
\text { з споживачем }\end{array}$ & $\begin{array}{l}\text { Операція «один } \\
\text { до багатьох» }\end{array}$ & $\begin{array}{l}\text { Взаємовідносини } \\
\text { «один до одного» }\end{array}$ & $\begin{array}{l}\text { Співробітництво } \\
\text { «багатьох } \\
\text { до багатьох» }\end{array}$ & $\begin{array}{l}\text { Вплив на пове- } \\
\text { дінку, врахування } \\
\text { індивідуальних } \\
\text { інтересів }\end{array}$ \\
\hline
\end{tabular}


сайту, який включає в себе: пошукове просування; контекстну рекламу; e-mail-маркетинг; інструменти всередині сайту; прихований маркетинг; роботу 3 блогами, соціальними мережами тощо.

Оскільки, як було зазначено, особливістю В2В-маркетингу $€$ більш тісний контакт між продавцем та клієнтом, то слід погодитись 3 Т. Старицьким, який в роботі [9, с. 495-496] пропонує трьох ступеневу модель роботи 3 клієнтами, яка складається 3 таких етапів: налагодження зав'язків з клієнтом, виявлення їх ключових потреб та розробка контуру зворотного зв'язку; вдосконалення рекламних пропозиції та завоювання прихильності і лояльності клієнтів; встановлення максимального рівня співпраці з клієнтами.

В статті [10] наголошується на важливій ролі стратегічного аспекту в структурі В2В маркетингу, тому й коксохімічні підприємства більше не можуть ігнорувати нову онлайн-реальність. Систематизація основних обзорів таких трендів за матеріалами інтернету [1; 11] дозволяє сорормулювати основні особливості сучасного рекламного менеджменту на В2В ринках в цілому та ринку коксохімічної продукції, зокрема.

Серед таких трендів, які існують на протязі останніх років, слід зазначити наступні.

По-перше - це контент-маркетинг, який включає до себе не лише підбір слів у тексті на сайті підприємства 3 метою пошукової оптимізації, лінкування для підвищення рангу сторінки у системах пошуку, але й про брендовану журналістику, зображеннями, відео, веб-аплікаціями - емоціями та інформацією.

Як зазначено в [11], дослідження показали, що 91\% клієнтів В2В надають перевагу інтерактивному візуальному контенту, а відеоконтент складає 82\% інтернет-трафріку. Тенденціями інтерактивного, візуального контенту в 2020 році за оцінками експертів [11] €:

інвестиції у відео (короткі, довгі, онлайн) стануть більш помітними;

застосування короткого відео «snackable» для використання на веб-сайтах та у соціальних мережах;

застосування прямих трансляцій подій як альтернативи вебінарам;

відродження інфографіки та більш помітне застосування інтерактивної інфрограсріки;

більш розповсюджене застосування графріки дій та анімації для пояснення продуктів, процесів та складних даних;

значна увага приділятиметься більше розповсюдження більшої кількості відеоконтенту через Instagram, Linkedln i Facebook; часте використання на сайтах В2В фронових відеороликів, візуалізації даних та інших фрорм інтерактивного контенту;

використання вікторин та онлайн-голосувань для залучення потенційних клієнтів.

В цьому аспекті, враховуючи важливість стратегічного спрямування рекламного менеджменту, необхідна розробка контентстратегії для бренду. Це збігається з останніми трендами В2В маркетингу в 2020 році, наведеними в [11], де перше місце посіли стратегічна направленість та економний маркетинг, що призводить до зменшення широти охвату маркетингової діяльності з акцентом на продажі. Все це призводить до появи все більшої кількості інструментів Martech, за допомогою яких є можливість управління рекламними кампаніями в різних каналах, розвитку соціальних мереж, автоматизації оцінки реклами, аналізу даних про користувачів, а отже швидкого виконання різних завдань рекламного менеджменту.

Швидке зростання кількості таких інструментів в останні роки призвело до інтеграції даних та появи спеціалізованих платформ та маркетплейсів.

Наступний тренд, який розвивається багатоаспектно, $є$ клієнт-орієнтований або клієнтбазований підхід. В царині В2В маркетингу він включає до себе так званий «досвід клієнта», який включає до себе досвід співробітників та досвід брендів. Такий підхід реалізується через впровадження ABM (Account Based Marketing), який $є$ стратегічним підходом до роботи 3 обраними ключовими клієнтами, враховуючи стратегічних ключових клієнтів або окремі цільові групи. В межах цього підходу надається підтримка взаємодії протягом усього життєвого циклу клієнта, використовується сучасний маркетинговий інструментарій споживацького досвіду. Останніми роками АВМ сполучається з персональним маркетингом та надточним таргетингом, що дає змогу здійснювати індивідуальну роботу 3 клієнтами, засновану на отриманні його поведінкових патернів через збір даних в Інтернеті в режимі реального часу.

Іншою тенденцією сучасного В2В маркетингу є використання даних, отриманих з різних джерел за допомогою різноманітних маркетингових інструментів. Така інтеграція маркетингових даних дозволить планувати та оцінювати есрективність маркетингової кампанії за двома підходами - традиційним і креативним. Для практичної реалізації обох підходів необхідно створити власний інтерфейс для оцінки маркетингових комунікацій, який дозволить підрахо- 
вувати кількість контактів та вартість кожного 3 них. Отримати власний інтерфейс можливо шляхом купівлі існуючого або замовлення його програмування в IT-спеціалістів.

Наступним трендом $€$ застосування холістичного підходу на основі психографрічного сегментування цільових аудиторій. Холізм - це (англ. holism, з грец. - цілий, увесь) - напрям західної фрілософрії, що розглядає цілісність світу як наслідок творчої активності містичного поля цілісності [12, с. 440]. Виходячи 3 цього, на основі холістичного підходу кожен елемент маркетингу повинен за своєю сутність та фрункціями розглядатися як єдине ціле [13]. Але, водночас, під час формування медіа-міксу для кожного сегменту, визначеного на основі психограсрії клієнтів, доцільно застосовувати його внутрішній креативний потенціал. Такий підхід дозволить сорормувати таку систему маркетингу та створити таку рекламу, при якій всі елементи будуть однаково важливими.

Іншим сучасним трендом $€$ використання так званого «єдиного екрану». Сьогодні в суспільстві широко використовується велика кількість планшетів та смартфонів з функціями комунікаторів. Вони витісняють комп'ютери у сорері медіа комунікацій. У напрямку розвитку цих гаджетів людство рухається у напрямку єдиного екрану, який буде меншим, ніж планшет, але більшим за розміром, ніж звичайний смарторон. У майбутньому такий «єдиний екран» буде основним гаджетом для споживання медіа-комунікацій. Тому маркетологам вже сьогодні необхідно готуватися до цього - створювати мобільні версій сайтів та оптимізовувати усі ресурси під мобільні пристрої та планшети.

Також маркетологам та рекламодавцям потрібно приділяти увагу створенню власних додатків, які дозволять наповнити веб-сайти додатковим функціоналом та контентом [14]. Необхідно «потоваришувати» із операційними системами, приймати участь у створенні, тестуванні, адаптації нових додатків, ділитися контентом у бета-версіях. Все це дозволить завоювати нових клієнтів.

Іншим корисним інструментом стає кросмедійне промо, яке базується на спонсорстві медіапроектів та дозволяє побудувати та використовувати для власного продукту цілу онлайн та офрфлайн комунікаційну платорорму.

Також не можна забувати про важливість використання інтернету для інтенсисрікації продажів - гео-локалізація, онлайн-знижки на офрфлайн покупки тощо. Як стверджував Е. Фрідляйн, директор агентства Econsultancy: «Близько той час, коли сайтом для багатьох компаній, особливо локальних, стане Google Business Listing» [14]. Сьогодні ж, в умовах пандемії COVID-19, створення інтернет-магазинів та інших онлайнсервісів $\epsilon$ «must have» для більшості компаній.

Отже, виходячи із усіх наведених трендів сучасного В2В маркетингу маркетологам та рекламодавцям необхідно запроваджувати нові підходу, не боятися експериментувати, при чому на експерименти в галузі маркетингу та медіа-комунікацій потрібно планувати бюджет.

Висновки. Таким чином, можна зробити висновок, що для успішного функціонування підприємств, у тому числі коксохімічної промисловості, необхідно застосувати рекламу їхніх продуктів. Серед сучасних трендів рекламного менеджменту особливу роль відіграють засоби інтернет-маркетингу. Особливо це стало актуальним в період локдаунів та карантинних заходів внаслідок пандемії COVID-19. Сьогодні деякі види інтернет-реклами стали вже «нео-традиційними», тому її потрібно використовувати скрізь.

\section{СПИСОК ВИКОРИСТАНИХ ДЖЕРЕЛ:}

1. Дослідження ринку інтернет-реклами в Україні за 2020 рік. 2020. URL: https://sostav.ua/publication/ rezultati-dosl-dzhennya-nternet-reklami-v-ukra-n-za-2020-r-k-87942.html

2. Мороз Л.А., Чухрай Н.І. Маркетинг. Львів : БЦ «Ажур», 2013.

3. Блейхман О.И., Пантюхин В.А. Особенности маркетинга рынка В2В. Маркетинг и маркетинговые исследования. 2006. 1, 52-60.

4. Литовченко І.Л. Маркетингові дослідження ринку В2В в Інтернет-середовищі. Вісник соціально-економічних досліджень. 2011. 41(2), 76-83.

5. Пісна О. Особливості маркетингу на ринках товарів промислового призначення. Ринок цінних паперів України. 2014. 8, 63-69.

6. Kotler, P., Kartajaya, H. \& Satiawan, I. Marketing 3.0. USA : John Wiley \& SONS, INC., 2011.

7. Семенова Л.Ю., Даценко В.В., Хурдей В.Д. Маркетинг 4.0. Ефективна економіка. 2020. № 11. URL: http://www.economy.nayka.com.ua/?op=1\&z=8322 DOI: 10.32702/2307-2105-2020.11.60

8. Чухрай Н.І. Промисловий маркетинг у сучасних умовах господарювання. Вісник Національного університету «Львівська політехніка». 2013. 754, 92-98. 
9. Старицький Т.М. Використання сучасного інструментарію та технологій В2В маркетингу. Глобальні та національні проблеми економіки. 2015. 7, 493-496. URL: http://global-national.in.ua/issue-7-2015/15-vipusk-7veresen-2015-r/1267-staritskij-t-m-vikoristannya-suchasnogo-instrumentariyu-ta-tekhnologij-b2b-marketingu

10.Гірний Н.Ю., Глинська О.Б., Мороз Л.А. Сутність управління рекламною діяльністю на підприємстві. Наукові записки Львівського університету бізнесу та права. 2017. T. 18. С. 38-42. URL: https://nzlubp.org.ua/ index.php/journal/article/view/8/7

11. 8 трендов B2B-маркетинга в 2020 году. 2020. URL: https://www.space.ua/8-trendov-b2b-marketinga-v2020-godu/

12. Константинов Ф.В. (Ред.). Философрская энциклопедия. Москва: Советская энциклопедия, 1970. Т. 5.

13. Чайка І.П. Холістичний маркетинг і його значення у фрункціонуванні вищого навчального закладу. Маркетинг і менеджмент інновацій. 2013. 3, 53-60. URL: https://mmi.fem.sumdu.edu.ua/sites/default/files/ mmi2013_3_53_60.pdf

14.Найближче майбутнє реклами: єдиний екран, крос-медійне промо, інтеграція даних... URL: $\quad$ https://ms.detector.media/onlain-media/post/10410/2011-02-09-nayblyzhche-maybutnie-reklamy-iedynyyekran-kros-mediyne-promo-integratsiya-danykh/

\section{REFERENCES:}

1. Doslidzhennia rynku internet-reklamy v Ukraini za 2020 rik [Research of the Internet advertising market in Ukraine for 2020] (2020). Retrieved from: https://sostav.ua/publication/rezultati-dosl-dzhennya-nternet-reklami-vukra-n-za-2020-r-k-87942.html (in Ukrainian)

2. Moroz, L.A. \& Chukhraj, N.I. (2013) Marketynh [Marketing]. L'viv: BTs «Azhur». (in Ukrainian)

3. Blejhman, O.I. \& Pantjuhin, V.A. (2006) Osobennosti marketinga rynka B2B [Features of B2B market marketing]. Marketing i marketingovye issledovanija - Marketing and marketing research, 1, 52-60. (in Russian)

4. Lytovchenko, I.L. (2011) Marketynhovi doslidzhennia rynku B2B v Internet-seredovyschi [B2B market research in the Internet environment]. Visnyk sotsial'no-ekonomichnykh doslidzhen' - Bulletin of socio-economic research, 41(2), 76-83. (in Ukrainian)

5. Pisna, O. (2014) Osoblyvosti marketynhu na rynkakh tovariv promyslovoho pryznachennia [Features of marketing in the markets of industrial goods]. Rynok tsinnykh paperiv Ukrainy - Securities Market of Ukraine, 8, 63-69. (in Ukrainian)

6. Kotler, P., Kartajaya, H. \& Satiawan, I. (2011) Marketing 3.0. USA: John Wiley \& SONS, INC.

7. Semenova, L. Yu., Datsenko, V. V. \& Khurdej, V. D. (2020) Marketynh 4.0 [Marketing 4.0]. Efektyvna ekonomika - Efficient economy, 11. Retrieved from: http://www.economy.nayka.com.ua/?op=1\&z=8322 DOI: 10.32702/ 2307-2105-2020.11.60 (in Ukrainian)

8. Chukhraj, N.I. (2013) Promyslovyj marketynh u suchasnykh umovakh hospodariuvannia [Industrial marketing in modern business conditions]. Visnyk Natsional'noho universytetu «L'vivs'ka politekhnika» - Bulletin of the National University «Lviv Polytechnic», 754, 92-98. (in Ukrainian)

9. Staryts'kyj, T.M. (2015) Vykorystannia suchasnoho instrumentariiu ta tekhnolohij B2B marketynhu [Use of modern tools and technologies of B2B marketing]. Hlobal'ni ta natsional'ni problemy ekonomiky - Global and national economic problems, 7, 493-496. Retrieved from: http://global-national.in.ua/issue-7-2015/15-vipusk-7-veresen2015-r/1267-staritskij-t-m-vikoristannya-suchasnogo-instrumentariyu-ta-tekhnologij-b2b-marketingu (in Ukrainian)

10. Hirnyj, N.Yu., Hlyns'ka, O.B. \& Moroz, L.A. (2017) Sutnist' upravlinnia reklamnoiu diial'nistiu na pidpryiemstvi [The essence of advertising management at an enterprise]. Naukovi zapysky L'vivs'koho universytetu biznesu ta prava - Scientific Notes of Lviv University of Business and Law, vol. 18, 38-42. Retrieved from: https://nzlubp.org.ua/ index.php/journal/article/view/8/7 (in Ukrainian)

11. 8 trendov B2B-marketinga v 2020 godu [8 B2B Marketing Trends in 2020] (2020). Retrieved from: https://www.space.ua/8-trendov-b2b-marketinga-v-2020-godu/ (in Russian)

12. Konstantinov, F.V. (Ed.). (1970) Filosofskaja jenciklopedija [Philosophical Encyclopedia]. Moscow: Sovetskaja jenciklopedija, t. 5. (in Russian)

13. Chajka, I.P. (2013) Kholistychnyj marketynh i joho znachennia u funktsionuvanni vyschoho navchal'noho zakladu [Holistic marketing and its importance in the functioning of higher education]. Marketynh i menedzhment innovatsij - Marketing and innovation management, 3, 53-60. Retrieved from: https://mmi.fem.sumdu.edu.ua/sites/ default/files/mmi2013_3_53_60.pdf (in Ukrainian)

14. Najblyzhche majbutnie reklamy: iedynyj ekran, kros-medijne promo, intehratsiia danykh... [The near future of advertising: single screen, cross-media promo, data integration...]. Retrieved from: https://mmi.fem.sumdu.edu.ua/ sites/default/files/mmi2013_3_53_60.pdf (in Ukrainian) 